\title{
Campur Kode Bahasa Sunda Ke Dalam Bahasa Arab Pada Percakapan Santri Pondok Pesantren Al-Basyariyah Cigondewah Bandung (Kajian Sosiolinguistik)
}

\author{
Oleh: \\ Fildzah Arifah Yoda, Yadi Mardiansyah \\ UIN Sunan Gunung Djati \\ fildzaharifah42@gmail.com, nashr7@uinsgd.ac.id
}

\begin{abstract}
Penelitian ini bertujuan untuk mengetahui bentuk-bentuk dan faktor-faktor campur kode pada tuturan bahasa Sunda ke dalam bahasa Arab santriwati pondok pesantren Al-Basyariyah. Pendekatan pada penelitian ini menggunakan pendekatan sosiolinguistik dengan teori campur kode Muysken, yang membagi bentuk campur kode ke dalam tiga yaitu penyisipan (insertion), alternasi (alternation), dan leksikalisasi kongruen (congruent lexicalization). Campur kode merupakan salah satu fenomena berbahasa yang menggunakan dua bahasa atau lebih dalam satu ujaran. Pada penelitian ini menggunakan metode deskriptif kualitatif. Adapun metode pengambilan data berupa metode simak dengan teknik sadap dan catat, dan metode cakap dengan teknik pancing berupa wawancara dengan beberapa pertanyaan untuk responden.
\end{abstract}

\section{KEYWORDS:}

Sosiolinguistik, Campur Kode, Muysken

\section{PENDAHULUAN}

Bahasa merupakan salah satu kebutuhan pokok manusia yang menjadi alat komunikasi untuk berinteraksi dalam lisan maupun tulisan. Bahasa pula berfungsi untuk mengungkapkan maksud dan tujuan penutur atau masyarakat dwibahasa. Dan bahasa merupakan bunyi untuk mengekspresikan pemikiran (Taufiq, 2015, hal. 2).

Bahasa yang terdapat di negara ini ada berbagai macam, sehingga masyarakat dwibahasa mempunyai kemampuan dalam berbahasa lebih dari dua bahasa. Masyarakat yang mempunyai kemampuan dalam menggunakan dua bahasa atau lebih disebut bilingualisme. Bilingualisme adalah seseorang yang memiliki kemampuan berbicara dengan dua bahasa 
atau lebih. Fenomena bilingualisme bisa terjadi dalam lingkungan pendidikan, karena pada lembaga pendidikan siswa diajarkan bahasa asing, yang mempengaruhi siswa untuk berbicara menggunakan dua bahasa. Lembaga pendidikan yang mengalami tuturan dua bahasa adalah pondok pesantren, karena di dalam pondok pesantren terdapat berbagai macam asal daerah yang mengakibatkan tuturan dua bahasa. baik secara individu atau kelompok masyarakat, fenomena bilingualisme pandangannya bervariabel dan tingkatan pada lingkungannya terdapat masyarakat pengguna dua bahasa atau lebih dalam keahliannya dan dalam hal kedudukan serta fungsi bahasa sosial (لعيبي, 2009, hal. 43). Selain itu, di dalam pondok pesantren biasanya mempelajari dua bahasa Asing seperti bahasa Arab dan bahasa Inggris. Salah satu faktor adanya bilingualisme adalah keberagaman bahasa.

Dalam berbahasa ada keragaman bahasa yang menunjukkan situasi dan kondisi keformalan tuturannya. Ragam bahasa menentukan tingkat keformalan pada interaksi seorang penutur. Ragam bahasa yang digunakan Martin Jose (1961) dalam bukunya the fife clock ialah ragam beku (frozen), ragam baku, ragam konsultatif, ragam santai (casual), dan ragam intim (Chaer dan Agustina, 2010). Keragaman bahasa tersebut bisa terjadi dalam fenomena kebahasaan salah satunya yaitu campur kode.

Campur kode merupakan peristiwa pencampuran dua bahasa atau lebih yang dilakukan secara bergantian dalam satu ujaran. Fenomena campur kode terjadi karena latar belakang penutur yang menguasai bahasa ibunya. dan menggunakannya ketika berbicara dengan orang lain yang berbeda suku. Campur kode juga merupakan penggunaan bahasa dari bahasa satu ke bahasa lain guna untuk memperluas gaya bahasa (Kridalaksana, Kamus Linguistik, 2008, hal. 40). Istilah campur kode digunakan untuk menggantikan bahasa yang satu dengan bahasa yang lainnya, terutama dalam sintaksis, morfologi dan lain sebagainya. Istilah ini 
digunakan untuk menggambarkan situasi yang lebih stabil apabila tidak menggunakan struktur bahasa dalam penggunaannya (المعرفة, 2007).

Campur kode dibagi menjadi dua, yaitu campur kode ke luar (outer code mixing) dan campur kode ke dalam (inner code mixing). Campur kode ke luar adalah campur kode yang berasal dari bahasa asing (bahasa kedua) atau bahasa ibu (bahasa pertama) yang bercampur dengan bahasa asing. Sedangkan campur kode ke dalam adalah campur kode yang berasal dari bahasa ibu (bahasa pertama) dengan segala variasinya, seperti bahasa resmi dengan bahasa non resmi (Suandi, 2014, hal. 140).

Pondok pesantren modern merupakan lembaga pendidikan yang mengutamakan berbahasa, baik bahasa Inggris ataupun bahasa Arab. Karena para santri mempunyai kemampuan dalam menggunakan dua bahasa atau lebih, maka tuturan yang sering digunakan para santri ialah tuturan campur kode. Salah satunya ialah pondok pesantren Al-Basyariyah, yang mengharuskan para santri untuk menggunakan bahasa Inggris atau Arab. Dengan menguasai dua bahasa bahkan lebih, mayoritas santri lebih sering menggunakan dua bahasa dalam satu tuturan. Latar belakang para santri kebanyakan berasal dari Sunda, oleh sebab itu kode yang sering dicampurkan dalam tuturan berupa kode Sunda.

Muysken membagi campur kode menjadi tiga bagian, penyisipan (insertion), alternasi alternation), dan leksikalisasi kongruen (congruent lexicalization). Adapun penyisipan yaitu campur kode yang hanya menyisipkan kata dan frase, alternasi merupakan campur kode dari bentuk kalimat dari yang kompleks berupa klausa yang digunakan dalam satu ujaran, dan Leksikalisasi kongruen yaitu campur kode yang polanya berbeda dalam suatu ujaran (Jayadi, 2011).

\section{LANDASAN TEORITIS DAN METODE}

Metode yang digunakan dalam penelitian ini berupa metode penelitian deskriptif kualitatif, yaitu metode penelitian yang objek 
penelitiannya berdasarkan fakta-fakta yang tampak sebagaimana adanya. Adapun jenis penelitian ini merupakan salah satu dari jenis penelitian kualitatif (Nugrahani, 2014: 96).

Teknik pengumpulan data pada penelitian ini menggunakan metode simak dan wawancara. Metode simak adalah metode pengumpulan data yang dilakukan dengan cara mengamati atau menyimak (Mahsun, 2014, hal. 243). Peneliti melakukan pengamatan dengan cara menyadap dengan merekam percakapan mereka secara spontan tanpa diketahui santri-santri disana. Kemudian seselesainya pengambilan data, peneliti mentranskipkan rekamannya.

Adapun pada metode cakap atau wawancara dalam penelitian ini dengan melakukan percakapan dengan responden. Metode pada penelitian ini menggunakan metode pancing, peneliti memancing informan untuk berbicara. Informan adalah narasumber dari bahan penelitian, pemberi informasi dan pembantu si peneliti dalam tahap pemerolehan data (Mahsun, 2014, hal. 251). Peneliti mewawancara dengan beberapa pertanyaan kepada partisipan, agar terpancing untuk berbicara dengan bahasa yang berupa campur kode. Pada teknik ini terdapat juga klarifikasi, yaitu peneliti menanyakan kepada responden terkait usia, kelas, dan asal daerah bagi santri yang tertangkap dalam rekaman di objek penelitian ini. Dan pada metode simak peneliti menggunakan cara dengan menyimpan ponsel untuk merekam percakapan dari santri-santri.

\section{HASIL DAN PEMBAHASAN}

Setelah peneliti melakukan pengamatan di tempat penelitian, peneliti menyimpulkan bahwa pada percakapan santri di pondok pesantren AlBasyariyah lebih sering ditemukan menggunakan campur kode. Adapun data hasil penelitian yang peneliti temukan adalah campur kode ke luar (outer code mixing) berupa penyisipan (insertion), dan leksikalisasi kongruen (congruent lexicalization), sebagai berikut: 
Campur kode bentuk penyisipan (insertion):

B1: "atuh ih ana laa urid muhadhoroh munfarid mah."

A': "laa munfarid ai anti, eh na'am deng munfarid."

Pada kalimat "atuh ih ana laa urid muhāọharah munfarid mah" menunjukkan tuturan campur kode ke luar (outer code mixing) yang berbentuk penyisipan (insertion). Penutur $\mathrm{B}^{1}$ mencampurkan kode pada tuturan yang ia gunakan, yakni kode Arab "ana laa urid muhāọharah munfarid" (أنا لاأريد محاضرة منفرد) dengan kode Sunda "mah dan atuh ih" (partikel dalam kode Sunda dan kata interjeksi), (saya tidak ingin muhāọharah sendiri(-an). Pada kata munfarid menunjukkan ḍamir untuk laki-laki, sedangkan penutur adalah perempuan, jadi kata yang tepat untuk ḍamir perempuan adalah "munfaridah"( منفردة). Penutur B menggerutu karena ia tidak ingin tampil untuk muhāọharah sendiri, karena teman yang lainnya sedang berhalangan untuk mengikuti acara muhāọharah.

Selanjutnya pada kalimat "laa munfarid ai anti, eh na'am deng munfarid" menunjukan tuturan campur kode ke luar (outer code mixing) yang berbentuk penyisipan (insertion). Penutur $\mathrm{A}^{1}$ mencampurkan bahasa yang ia gunakan, yakni kode Arab "laa munfarid ... anti" (لا منفرد ... أنت), dan kode sunda "ai" (partikel dalam bahasa Sunda) sedangkan kode Indonesia "deng" (kode Indonesia gaul) "eh" (kata interjeksi), (tidak sendiri(-an), eh iya (ternyata) sendiri). Pada kata munfarid menunjukkan damir untuk laki-laki, sedangkan penutur adalah perempuan, jadi kata yang tepat untuk damir perempuan adalah "munfaridah"( منفردة). Pada kalimat tersebut penutur mencampurkan kode Indonesia karena terbiasa dengan kata "deng". Penutur memberitahu kepada temannya bahwa ia tidak tampil sendirian, sambil ia melihat daftar yang tampil hari itu, kemudian ia memberitahu kembali kepada temannya bahwa hari itu ternyata dia tampil sendirian. Faktor yang menyebabkannya ialah mitra tutur yang berlatar belakang sama. 

A': "ustādzah, endog wāhid."
B1: "Sarah ih anti billughah sundawiyah."

Pada kalimat "ustadzah, endog wāhid" menunjukkan tuturan campur kode ke luar (outer code mixing) yang berbentuk penyisipan (insertion). Penutur $\mathrm{A}^{1}$ mencampurkan kode pada tuturan yang ia gunakan, yakni kode Sunda endog, sedangkan kode Arab "ustādzah" (أستاذة) "wāhid" (واحد), (ustadzah, telor (nya) satu). Penutur sedang mengantri makan dan menyebutkan lauk apa yang akan ia beli. Penutur mencampurkan kode Sunda karena faktor latar belakang dari si penutur yaitu suku Sunda.

Campur kode bentuk leksikalisasi kongruen (congruent lexicalization):

$$
\begin{aligned}
& \text { A': "Zalik Ica maujūd, Zahro. Anti ga ada khimār?" } \\
& \text { B': "iya." }
\end{aligned}
$$

$A^{2}$ : "ana ada sok ambil di bawah. Ana mah maujud-nya libas faqot."

Pada kalimat "ana ada sok ambil di bawah. Ana mah maujud-nya libas faqot" menunjukan tuturan campur kode ke luar (outer code mixing), yang berbentuk leksikalisasi kongruen (congruent lexicalization). Penutur $\mathrm{A}^{2}$ mencampurkan tiga tuturan sekaligus dalam tuturannya, yakni kode Arab "anā maujūd libās faqot" (لباس فقط أنا موجود), sedangkan dalam kode Indonesia "ada ambil di bawah", dan dalam kode Sunda "sok..mah.." (partikel dalam bahasa Sunda), (saya ada (kerudung) silahkan ambil di bawah (lemari). Saya adanya baju saja). Penutur A memerintahkan kepada lawan tutur B untuk mengambil kerudungnya di lemari bagian bawah. Dan di lanjut dengan kalimat "anā mah maujūd nya libās faqat" tuturan tersebut untuk memberi tahu kepada lawan tutur. Kode Sunda yang penutur ucapkan disebabkan faktor latar belakang si penutur yaitu suku Sunda.

B2: "Hah? Jangan di i'lan! Ukhti kabiroh nanti yang the bad gimana?" 
C': "Diberdiriin di masrah. Antunna, kalo ukhti kabiroh nya ga pake jaurab jangan diikutin ya! Nanti mah biasain pake lughah di hujroh, biar kebiasa diluarnya ya!"

Pada kalimat "Antunna, kalo ukhti kabirah nya ga pake jaurab jangan diikutin ya! Nanti mah biasain pake lughah di hujrah, biar kebiasa di luarnya ya!" menunjukkan tuturan campuran kode ke luar (outer code mixing) yang berbentuk leksikalisasi kongruen (congruent lexicalization). Penutur $\mathrm{C}^{1}$ mencampurkan kode pada tuturan yang ia gunakan, yakni kode Indonesia "kalo" (kalau) "ga pake" (tidak pakai), "jangan diikutin ya, nanti biasain pake ... , biar kebiasa di luarnya" dengan kode Arab "antunna" (أنتن), "ukhti kabirah" (أختي كبيرة), "jaurob" (جورب), “lughah" (لغة) "hujrah" (حجرة) dan kode Sunda "mah" (partikel dalam bahasa Sunda), (kalian (anak asuh), kalau kakak (pr) nya tidak memakai kaoskaki jangan diikutin ya! Nanti biasakan memakai bahasa (Arab/lnggris) di kamar, biar terbiasa di luarnya, ya). Pengasuh kamar yang satunya memerintahkan kepada anggota kamarnya yang jarang menggunakan kaoskaki dan bahasa agar menggunakannya. Karena itu salah satu peraturan dari pengurus organisasi santri. Keterbatasan dalam kosakata menjadikan faktor terjadinya campur kode pada tuturan di atas.

\section{PENUTUP}

Berdasarkan hasil analisis pada sebelumnya terkait campur kode pada percakapan santri Pondok Pesantren Al-Basyariyah dapat disimpulkan sebagai berikut:

Klasifikasi campur kode berdasarkan struktur yaitu penyisipan dan leksikalisasi kongruen. Adapun bentuk-bentuk campur kode berupa:

Penyisipan (insertion). Dalam data yang ditemukan penyisipan berupa kata dan frase pada bahasa non arab dan ke dalam unsur-unsur 
atau kalimat bahasa pertama (Arab). Unsur yang dimasukkan dalam penyisipan ini berupa konstituen yang berbentuk kata dan frasa.

Leksikalisasi kongruen (congruent lexicalization). Dalam data yang ditemukan pada bab sebelumnya yaitu leksikalisasi kongruen yang proses campur kode polanya berbeda dari bahasa yang berbeda pula dalam suatu ujaran.

Tuturan berupa campur kode tidak lepas dari faktor-faktor yang mempengaruhinya. Adapun faktor-faktor yang mempengaruhinya, yaitu (1) latar belakang penutur, Campur kode yang terjadi karena faktor latar belakang penutur yang berasal dari Jawa Bawat mayoritas menggunakan kode Sunda dalam tuturannya; (2) perjelasan dan perhalusan permintaan, Campur kode terjadi karena faktor ini yang dilakukan agar makna dan tujuan tersampaikan dengan jelas kepada mitra tutur; (3) kebutuhan leksikan, Campur kode terjadi karena faktor penutur tidak menemukan padanan kata yang tepat, sehingga muncul penggunaan bahasa asing yang lebih sederhana dan mudah dipahami.

Dari hasil penelitian yang peneliti dapatkan selama di pondok pesantren Al-Basyariyah, mayoritas santri masih menggunakan atau mencampurkan bahasa asing terutama bahasa Sunda ke dalam tuturan bahasa Arab, baik dari bahasa ataupun strukturnya.

Setelah melakukan penelitian terhadap campur kode pada percakapan santri pondok pesantren Al-Basyariyah, peneliti akan memaparkan beberapa saran, guna untuk meningkatkan dalam percakapan di pondok pesantren Al-Basyariyah, yaitu: (1) Peraturan dalam berbahasa lebih ditegaskan lagi, seperti melarang santri melakukan 2 bahasa dalam satu ujaran, karena selama ini santri hanya diharuskan untuk berbahasa saja, bukan diharuskan untuk berbahasa dengan baik dan benar. Memang terlihat sulit, namun jika dibiasakan akan terasa mudah; (2) Mengajarkan fonologi (makharijul huruf) dengan baik dan benar, agar para santri tidak 
salah dalam mengucapkan yang berakibat salah arti; (3) Dalam penelitian ini hanya membahas terkait campur kode dalam percakapan santri, namun untuk alih kode dan interferensi fonologi peneliti belum menemukan penelitian terkait hal tersebut. Alangkahbaiknya alih kode dan interferensi fonologi perlu diteliti. Oleh karena itu, bagi peneliti selanjutnya diharapkan dapat meneliti terkait interferensi fonologi di pondok pesantren AlBasyariyah ini.

\section{DAFTAR PUSTAKA}

Chaer dan Agustina, A. C. (2004). Sosiolinguistik Pengantar Awal. Jakarta: Rineka Cipta.

Chaer dan Agustina, A. d. (2010). Sosiolinguistik Pengantar Awal. Jakarta: Rineka Cipta.

Jayadi, D. (2011). Campur Kode. Jurnal Bahasa, 20-28.

Kridalaksana, H. (2008). Kamus Linguistik. Jakarta: Gramedia Pustaka Utama.

Kridalaksana, H. (2008). Kamus Linguistik. Jakarta: Gramedia Pustaka Utama.

Mahsun, P. D. (2014). Metode Penelitian Bahasa. Jakarta: PT Raja Grafindo Persada.

Suandi, N. (2014). Sosiolinguistik. Yogyakarta: Graha IImu.

Taufiq, W. (2015). Fiqh Lughah. Bandung: CV. Nuansa Aulia.

المعرفة . Retrieved Juli 29, 2019, from خلط اللغات. (2007, Februari 16). خلط اللغات : خلط اللغاتhttps://www.marefa.org/

$$
\text { لعيبي, ا. ا. (2009). اللسانيات الاختماعية عند العرب. الأردن : دار اليازوري العلمية. }
$$

